\title{
Impact of COVID-19 on Teaching and Classroom Management: Thoughts Based on Current Situation and the Role of Communication
}

\author{
Panagiotis J. Stamatis
}

\section{ABSTRACT}

\begin{abstract}
The present article focuses on the impact that COVID-19 has on teaching and school classroom management that affect the whole school management as well. As the teaching circumstances are compulsory and dramatically changing and as face-to-face teaching is altering into distance teaching (e-teaching), the teaching features are deeply modified either it takes place in home or in school environment harming communication quality due to physical presence deprivation. Within this framework, present chapter aims at the presentation of teaching procedure developmental progress under the light of a historical overview upon this subject. Also, it aims at the presentation of distance learning as a modern teaching form which has intruded in traditional education reality by the emerged necessity related to entire population's protection against COVID-19 pandemic. Nevertheless, as it seems by the evolution of the facts, COVID-19 pandemic was simply speeding the introduction of distance learning into educational system which, more or less, was constituted a central choice for many states and governments. Furthermore, in this chapter a discussion takes place related to teachers', students'; and parents' reactions about the implementation of distant teaching. This discussion claims that the initial interest for distant teaching, had within few months converted into a boring and undesirable reality from which most involved persons wanted to be released as soon as possible. The chapter is completed with a reference to the purpose of educational community members and all educators in achieving their return into school's normality, namely in procedures and situations that were existed before COVID-19's pandemic advent.
\end{abstract}

Keywords: communication, COVID-19, e-teaching, physical presence teaching, school management.

\section{INTRODUCTION}

Within the framework of sudden changing due to COVID19 pandemic, governmental education authorities, educators, students and parents are requested to accept and be adjusted very fast to a new learning reality. In parallel, the school is rapidly changing as new teaching objectives and subjects are including in new curricula, new teaching methods based on e-Learning and teachers' roles are proposed as better than current ones. Consequently, all of these changes affects school administration and its human resource management. Furthermore, they affect the management of school finance resources, namely the funds that are necessary for the smooth function of the school along with many other factors of modern educational procedure.

Actually, this article is a theoretical one. It is based on across time description of classic or face-to-face teaching
Published Online: February 10, 2021

ISSN: $2736-4534$

DOI: $10.24018 /$ ejedu.2021.2.1.48

Panagiotis J. Stamatis*

Department of Sciences of Preschool Education and Educational Design,

University of the Aegean, GREECE (e-mail: stamatis@rhodes.aegean.gr)

*Corresponding Author process and its transformation to distance learning. Also, it focuses on reactions, behaviors; and desires of educational community members in regards to new teaching conditions and it describes the outcomes all of them so far. It concludes that argumentation among teaching with physical presence and e- Teaching constitutes an interesting study field not only for scholars who work upon the field of pedagogy but also to those who work on the field of communication and school management which has currently received new features and dimensions due to COVID-19 pandemic situation.

\section{LIFELONG TEACHING: AN OVERTIME APPROACH}

Making a synoptic and historical overview and calling back into memory what had already happened even from the twilight of the human history in regards to the starting of teaching procedure, from the very ancient times to the era of Plato and Aristotle and even older up to present time, 
instruction was over time based on face-to-face and immediate teaching methods. Either instruction was personalized or mass it was constantly based on interpersonal communication between teacher and student/students. Initially, in ancient times, teaching was taken place in private. Centuries after that, teaching became mass and later public. In both cases nevertheless, interpersonal and live communication was fundamental. Within this context teacher and student/students were together at the same space, the same time due to their bodily presence. Under those circumstances they communicated face-to-face (Stamatis, 2015; Solomon \& Theiss, 2013). Bodily and physical presence of teacher and student/students in the same place was always an insurance for pedagogical relation development based on real presence of persons -not a virtual one (Argyle, 2013). That was giving a meaning to educational procedure and was adding qualitative features to it much more than impersonal and virtual teaching situations might be able to give or add (McCroskey, Richmond, \& McCroskey, 2006).

Teacher's and student's physical presence in the same space, namely the classroom, as the communication which is conducted between them, are over time undoubtedly considered a prerequisite for instruction's quality and qualitative learning outcome (Simonds \& Cooper, 2011). Teacher, like any other educator man or woman who participates in a classic or traditional teaching procedure is always being on the side of every student with his/her own physical presence. So, he/has the ability among others: i. To be able to answer in every student's question, ii. To be able to immediately be involved in case he/she receives a calling of a student for help, iii. To be able to immediately be involved in case he/she see that a behavioral problem takes place, iv. To be able to provide advices, guidance, motives; and to encourage and award student if necessary (Stamatis \& Nikolaou, 2018).

In a teacher-centered educational system teacher's physical presence in the classroom is usually considered negative by the emotional side of a student. On the opposite, in a childcentric educational system it is positive pedagogically charged (Stamatis, 2014; McCroskey, Richmond, \& Bennett, 20060. For centuries child-centric educational system is considered the cornerstone of teaching processes. That is because child-centered procedure is based on interpersonal relationships which are founded on socio-emotional power of human contact, on immediacy and intimacy that develop between teacher and student inside the classroom (Pyrgiotakis, 2011).

Interpersonal communication is reasonably considered as the top of all instructional forms in every teaching procedure, which must not be lost or limited or irreplaceable from another instructional form despite the fact that something like this would be able to be done, given that modern technological means and implementations development are dynamically entered in all levels of human way of living (Garrison, 2017). But teaching process cannot and must not be comparing or relating to other activities of human daily life which are belonging in a wider cycle of job activities
(Stamatis, 2015). That is because instruction is not simply a work like any other. It is physical presence and interaction, a constant vigilance, compassion; and empathy. It is a soul offering.

\section{THE 'SUNRISE' OF DISTANCE TEACHING}

Few decades ago, is more than sure that many people could not even imagine that a severe reason might force them keeping themselves indoors trying to save their own life and the lives of people who are living or are in contact with them. Instead, current reality has shown that conditions of living nowadays have been changed dramatically on the planet. A problem which is created in south hemisphere can be rapidly expanded to north hemisphere of the earth, affecting the lives of million peoples quickly. The current case related to COVID-19 is an excellent paradigm that confirms this fact.

The most responsible of the governments around the world, trying to put limits in the spreading of that pandemic virus, had called on time all citizens to stay at home, avoiding vain traffic and people gathering. In this framework, schools' lockdown were estimated to be extremely necessary. This fact consists an impressive situation in global chronicles bearing in mind that school lessons canceled for the first time without war conditions existing that is a case in which only schools are closed mandatory (Miller \& Modi, 2020). Furthermore, the case of COVID-19 pandemic was considered like a world war which started by all mankind against to an invisible enemy who was rapidly known day by day not by its biological features but the consequences it caused to thousands of people and mainly to the elders and those with underlying disease. Most of those people became gravely ill, many of them were put into intubation and -unfortunatelypassed away, despite all laborious and dangerous efforts doctors and nurses had made along with many other hospital staff.

In order this emergency addressed and in order the contact of students with teachers and educational procedure to be continued, was decided by the Greek government e-Teaching and e-Learning procedures to be mandatory for a specific period of time (Stamatis, 2017). Within this framework of mediated teaching, all teachers were obliged to create a personal virtual class making use of computers and specific applications based on synchronous and asynchronous teaching methods in order their students have access to selfproduced mainly teaching material. The main purpose of this effort was students to be able to repeat the official school material through e-teaching. That material was been planned to be uploaded to each teacher's virtual class where students and parents had free access. During the initial stage of eteaching the participation of teachers was massive and impressive. That was something that pleased the ministry of Education along with the readiness and knowledge shown by the teachers to this new teaching reality.

In this specific way students had acquired the ability of partial engagement and communication with their teachers and parents had the possibility to attend the whole teaching procedure while they stays at home and taking the role of the guidance of their own child. Additionally, they had to buy 
computers and the rest of needed digital equipment for the necessities of e-teaching. So, the role of parents was extremely important and their participation more crucial than traditional teaching bearing in mind that parents should stand nearby their child especially to that of early age. This did not happen in traditional/face-to-face teaching as teachers had taken this role officially. Hence, the new reality made mandatory the change of roles it seems by the facts (Walsh, 2016).

In any case, communication between teachers and parents remains a very strong factor which affects determinedly the quality of learning process and educational work as a whole (Stamatis \& Kostoula, 2021; Velez \& Cano, 2012. In current teaching incident, teaching lacks its nonverbal dimension and perceives virtual reality as alive with the power that fantasy emits (Stamatis, 2013; Knapp \& Hall, 2010). Actually, distance teaching is nothing else than an online broadcast of an e-teaching via computer. In that case, communication between teachers and parents becomes further mandatory, necessary and useful (Argyle, 2013).

The mass interest shown by scholars to the newborn trend of distance learning is undoubtedly going to reveal very interesting aspects, will leads the scientific community to new research fields, the political and educational leaderships to new decisions oriented to new educational directions; and educational community to new efforts for implementing those decisions. It is quite obvious that the humanity has just started to look -among many other things- the sunrise of education as it will be implemented into the school of the 21 st century (Stamatis \& Goutziamanis, 2020).

In this school, communication will hold a distinctive place as it will be at the center of one of the most important literacies which is communication literacy (Stamatis, 2017). Under those new circumstances which are globally shaped, family is called to assume important role in regards to education of every child so that nobody of children stays back. The responsibility of the state is equal to that of family because it must attend and support all matters that opens new educational horizons to each member of the educational community and every learning society (Iordanidou, Stamatis \& Valsamidou, 2020).

\section{GOVERNMENTAL EFFORT OF DISTANCE TEACHING IMPLEMENTATION}

As it has been referred in recent research conclusions (Lemov, 2020; Sánchez, 2020), teachers face very often students' behavioral problems that diminish lessons' quality, create tensions in the classroom, disturb the existing relationships between teachers and students and consequently, cause an upset situation that affects the teaching climate. In many school units, teachers are invited to conduct a discussion upon this problem and make decisions in regards to its addressing along with specialists, parents and students where it is possible. Scholars have proposed various solutions to that very problem. Despite of this, the problem is remaining unsolved for decades and in many cases it increases. So, traditional classes are seemed weak to completely deals with this specific problem. In many cases, anyway, exceptions are observed taking for granted that a partial resolution of the problem is achieved. That is because competent and talented teachers invent ways and tests good practices which are related to what literature proposes. The implementation of that practices bring out a positive outcome indeed.

For the radical confrontation of that problem governmental initiatives were developed in some countries that are concentrated to students' behavior improvement based on appropriate methods. So, in modern time of pandemic COVID-19, distance teaching consists one of the mentioned methods. Children attend the distance lesson without causing troubles to teacher who teaches the lesson outside the environment of traditional classroom staying at school or even at home. In fact, distance teaching has the ability to maintain distances between students and between them and their teachers. This situation, despite the dysfunctions it may cause in teaching, operates as a safety valve to the development of annoying behaviors that students cause inside the classroom. This happens because students do not stay nearby each other and-consequently- they cannot disturb one another with chats developed among them, with cries or disturbing the teacher during teaching in various ways etc. In this way, tensions are addressed and finally, normalization in teaching program flow is achieved.

Several teachers wishing to demonstrate their skills in ICTs are encouraged by the ministries of education worldwide to use media along with soft wares and platforms of synchronous and asynchronous digital learning, which make much easier and accessible the distance education. For instance, soft wares like that are the e-class, e-me, webex, class web, bbb, zoom etc. are able to support distance learning. Furthermore, teachers are encouraged to use any other convenient mean, like social media or broadcast their teaching via live streaming, in order to be able to stay in constant digital contact with students keeping communication every day with them and exchanging questions, opinions and views related to lessons, to school life and generally, the educational procedure.

Within this framework, many governments provided free Wi-Fi services to teachers and students along with free electronic devices like tablets, computers etc. in order to facilitate the work of distance education which was promoted as a modern form of effective and innovative learning. Its ultimate purpose was probably the progressive replacement and finally, the abolition of teaching with physical presence because it is considered obsolete and extremely expensive. The cut down of expenses -especially for public educationconsists nowadays a great target for many governments and political leaderships of education ministries which are in line with this target as they are dreaming a future school operating with lower cost. The cut down of school unit budget as seemed does not particularly interest the governments, whether it relates to the creation of negative consequences in social development of students and to organization and structure of current educational reality or not. This reality consists a choice of those political leaderships who design and support the content and principles of the 21 st century school that is the school of globalization. 
What is seemed to truly interest modern political leaderships is that in globalization's school would not exist all types of deviant behaviors of students, that one which are opposed to classroom rules and create problems to teachers, to classmates and generally, to educational process. In this way, they believe that classroom management and discipline problems addressing students' deviant behavior will become more effective. Moreover, they believe that better security conditions to school environment will arise despite aggressive behavior being increased, inside and outside schools.

Once a teacher loses the control of his/her own classroom, it becomes extremely difficult to him/her to regain it back. So, teachers use the term 'classroom management' to describe the process of ensuring that classroom lessons run smoothly without disruptive behavior from students compromising the delivery of instruction. Also, they use this term to imply strategies that may prevent disruptive behavior preemptively, as well as effectively responds to it after it happens. Problems in this area causes some teachers to leave teaching, because disruptive behavior is a difficult aspect of teaching for many teachers. Classroom management supports the proper execution of curriculum development, developing best teaching practices, and putting them into action. Actually, classroom management is all actions and directions that teachers use to create a successful learning environment, a beneficial for teaching climate and learning atmosphere for the student. Teaching climate is closely related to be connected to school performance, such as students' achievement, engagement, confidence, classroom discipline; and school effectiveness. Within this framework effective classroom management involves clear communication of behavioral and academic expectations as well as a cooperative learning environment. As Arsenijevich, Andevski and Jockov (2017) stresses, "assessment of relations student-student and student-teacher should be considered primarily in the context of teachers' communication profile and some personality traits".

\section{DISTANCE TEACHING: REJOICE FOR CHILDREN AND DRAMA FOR PARENTS?}

In first phase of pandemic, the spokesperson of the Greek government, as others did in many countries, was appeared on television and announced to citizens that the number of COVID-19 cases is rapidly increases. Thus, schools should close for precaution reasons like any other public services and businesses as well. This will happen in order lockdown will take place and in this way the spreading of malignant virus be diminished. Then, the Ministry of Education confirmed on television news that it was truth. Additionally, it announced the schools' lockdown and asked teachers to start teaching via computers and students to attend those teaching distantly using computer or their personal smart phone.

In this way more or less, distance teaching was started and e-lessons were conducted. In the beginning, attendance of lessons in this new way was considered extremely interested by the children. Parents were excited as their children stayed safe at home. So, teachers, students and parents started working on e-Teaching procedures in order better learning outcomes be achieved using the innovative e-Teaching method. The older children were faster facilitated with eteaching method and knew how they could connected every day to their e-class in order they be able to attend the lessons. Instead, younger children had needed help of their parents in order they are able to attend their lessons as they should be linked to appropriate website.

Attendance of e-lessons through this procedure -albeit it was very interesting for a long time giving remarkable pleasure to participants and to Ministry of Education apparently- had gradually started to be fainted as it exhausted children. Probably, it was started to make children feel bored because after every e-lesson did not a break was been followed for play and discussion among classmates, while the children were should remain connected sitting in front of screens and unable to make movements or easily participate in e-lesson procedure like they used to do in real school classroom where they attended with physical presence. So, day by day children started to become more and more unquiet and unwilling to participate in e-Teaching and e-Learning process. They found it boring, uninterested and with no sense.

Parents of younger children were obliged to be constantly nearby them during e-Teaching trying to provide advices to them for better attending to e-lessons and make them keeping their glance focused on the computer's screen. But children were finding many reasons to detract their own attention. They were seeking reasons to stand up from their chair pretending that they needed to do some steps inside the study room or house. Furthermore, they found it extremely difficult to remain quiet for a long time concentrating their attention on the computer's screen. As the days passed, parents were getting more furious while they were losing their patience. Especially mothers who were involved in e-lessons process were more frustrated for their misfortune to participate in distance education and e-teaching process which was imposed because of COVID-19 pandemic. It is true that mothers were the most involved in this situation compared to fathers who were usually absent.

E-teaching lessons started gradually becoming a nightmare for children and parents. Disagreements, tensions and conflicts among parents and children were a daily matter. The most of e-lessons participants were prayed their new teaching "adventure" to be ending the sooner in order they be able to return to their everyday normality, namely to daily activities they had to do as they did before COVID-19 pandemic to time in which all lessons were been conducting with children's psychical presence and all school yards were crowded and plenty of happy children voices (Johnson \& Johnson, 2020). The isolation inside the home made children to desire their return back to school, despite the fact that many of them truly managed to attend the e-lessons in a satisfying way using computer and to acquire new knowledge in this way and sometimes even more than that they had learned participating physically in the school classroom (Stamatis \& Nikolaou, 2020).

Parents who were started with positive thoughts accepting and enjoying perhaps the new teaching method, finally they 
found out that this method was able to transform their everyday life into a nightmare. E-Teaching transformed parents' everyday life in real drama in the framework of which conflicts with children were gravely traumatizing their interpersonal relationships with children and possibly without a healing forever. Moreover, e-Teaching increased time children spent on computer usage that is extremely dangerous for children's personality development as known (Lynn \& Johnson, 2016). So, the initial happiness of parents converted finally into a drama which many wished to be put an end the sooner the possible (Bornstein, 2020). Apparently, eTeaching had disappointed most of children and parents. All situation looked like a thriller movie which starts with happy moments and ends after filling with pain, tension and fear the viewer's soul presenting to them many scenes of an unpredictable and complicated plot plenty of assassinations.

During the second stage of COVID-19 pandemic, the spokesperson of government had appeared again on television news announcing to viewers that cases of pandemic are uncontrollably increased. Despite this, he claimed that schools should not be locked down but, instead, lessons must be continued after school community members receiving necessary protection measures. Only the Universities, as well as few other public services alike and private sector, should stay closed for security reasons, namely the diminishing of COVID-19 cases spreading. Of course, this had not been said by chance. It covers probably a feasibility related to radical changes in operation of tertiary education. This feasibility will be disclosed veryttr soon.

\section{TEACHERS, STUDENTS AND PARENTS PREFER TEACHING WITH PHYSICAL PRESENCE AT A SCHOOL}

Experts on communication issues mention the importance of classroom communication. Among them Calitz, La Fuglestad and Lillejord (2002) stress that nobody can acquire high communication skills only by reading for them and studying them in books and other matters. Usual problems that modern teacher have to deal with are related to the lack of a sound culture of teaching and learning and lack of students' discipline (Stamatis \& Hatzinikolaou, 2020). Also, by the side of teachers, poor classroom management skills consists a reality. Especially within classroom environment, special communication strategies development needs more knowledge and experience. What very modern teacher particularly needs is long-term practice before he/she is about to implement communication strategies in teaching. He/she needs to think seriously about them and tests personal communication strategies and practices in order -sometime perhaps-he/she becomes communication competent (Velez \& Cano, 2012).

People interact through communication. Teaching and classroom management are developed communication through. Communication constitutes a mean through which various necessities, feelings, attitudes of teachers and students are expressed and transferred each other in order good collaboration and learning outcomes be achieved (Stamatis, 2015). If communication does not effective learning and teaching objectives cannot be reached
(Bambaeeroo \& Shokrpour, 2017). Consequently, every teacher must precisely know what effective communication means, what are the principles and conditions that make effective a communication process and which factors might harm it. Effective communication is usually achieved when the sending message is clearly understood by the receiver and when comments sent by the receiver to sender are accepted (Kruger \& Van Schalkwyk, 1997).

Can distance learning be effective? Yes, under some conditions it could be effective. Face-to-face communication is more effective than distance communication because it is not direct but mediated. Direct communication attracts more the interest of communicators, it is more pleasant and less boring than distance communication, which does not offer the amount of stimuli that facilitate understanding of exchanged messages amongst communicators in a simple and comprehensible way (DeVito, 2018).

When it does not happen, participants in communication process feel uncomfortable, they are feeling tired and seeking for avoiding participating in a communication process of that type. For all reasons mentioned above students, parents and teachers realize that direct and face-to-face communication is preferable and through this type of teaching better learning outcomes are achieved. Moreover, they seem to realize that classroom management becomes easier and without compulsory parents' presence as usually occurs in e-teaching. Furthermore, they realized that school environment constitutes a field of social learning and a space for children's practicum on social skills acquirement. This space in no way can be replaced by cyberspace, namely children's participation in distance teaching via an e-teaching platform. For that reason, the vast majority of educational community requires educational process to return to its classic normality that is face-to-face teaching in which e-teaching tools could be used of course along with ICTs and digital means increasing qualitative and quantitative enrichment of teaching with physical presence.

Most teaching community members around the world want to return to teaching with a physical presence as seen on social media and in newspapers. Nevertheless, the question that arises is: Will the world leaders, mechanisms and those who designed the 21 st century school model - which is based on neoliberalism - allow this desire to be fulfilled? The answer of this question includes huge dimensions as it has been connected to fundamental political choices that are related to structure and operation of future school, content and learning procedures and global financial issues. These matters are related to enormous fund investments in education areas where knowledge is offered and be received at home by knowledge seekers who desperately try to invest money buying knowledge for many cases. That seekers have the opportunity to make choices between cheap or expensive educational packets like consumers do while they are choosing the consuming products which are exposed on supermarkets' or other shops' racks.

In similar way, once the client cannot reach the shop, then he/she may give a delivery order at home, in case he/she wish to have receiving the ordered products there. Under these 
circumstances, those who are speaking about commercialization of knowledge lie nearby neoliberal theory point of view, despite education is not a product which could be created distantly and via computer. It is something inner and intellectual related to human physical presence and interaction that must not related to market rules. The essential purpose of education in its classic dimension was never only the transition or transferring of knowledge but, in parallel, the multisided human development of body, soul and spirit that which ancient Greeks called "paideia". This cannot be delivered by attending e-classes but by only participating and attending physically into traditional classrooms.

In regards to procedure and content of classroom and school management as a COVID-19 consequence, one could realize that an absolutely new reality has been created. The school reality has changed completely and that is exactly why school management has changed radically. It has been transformed into an unprecedented form that must be studied by scholars and experts in all its dimensions and consequences that are created by each of them. It is striking to every one when realizes that things are moved from the efforts made by educators to maintain the classroom order to the efforts of parents to convince their children to carefully attend e-lessons that are offered at home via computer.

So, the anxiety of teachers has been transformed into parents' anxiety. The effort of school head teacher to properly organize and co-ordinate teachers aiming at educational activities best achievement has been moved on teachers who have full responsibly for organizing the lessons and teaching using specific e-teaching platforms. The same has happened with the subject of communication with students and parents which has passed from head teachers to teachers.

In parallel, keeping students away than school on one side and their maintenance at home on the other side has contributed to limitation of bullying along with all unpleasant situations caused in children's social interactions in school environment. This might considered the only benefit which has been achieved from distance teaching. Despite this, the main wish of the majority of school community members remains the return to teaching with physical presence within real school environment whenever the vast majority of population be vaccinated with anti-COVID-19 vaccine. As a comparison measure is now existing by experience, the willingness for teaching with physical presence is higher than e-teaching along with interpersonal relationships which are empowering social contacts and vice versa.

To be more specific, most of the members of educational community are concerned that using of COVID-19 pandemic will transform the society to e-society, namely a society in which all jobs or things will be distantly accomplished using computers and special applications. All of them is estimated that gradually are going to isolate human activity and put it against social one which a day will be totally replaced. Some of the above mentioned applications are e-banking, eshopping, e-teaching, e-learning, e-booking, e-shopping, etc.

All applications are contributing to limit human presence and -consequently- to job positions diminishing. It means that gradually and after robots full introduction to production process, humanity will face great unemployment, namely poverty, starvation and social disruption with unpredictable consequences to violence increasing. This scenario scares every human who is barely surviving in the present and concerns for its future that seems difficult. Thus, return to life and habits before COVID-19 pandemic period of time constitutes a hopeful prospect to all people and especially those who are involved in educational process attending classes with physical presence. After all, everybody should has in mind what Aristotle has claimed once: "Man is by nature political animal", namely a social being and "He who is unable to live in society, or who has no need because he is sufficient for himself, must be either a beast or a god!' (Politics bk. 1, 1253a 2-3, 27-9 ref. in Ratcliffe, 2017).

\section{REFERENCES}

M. Argyle, Bodily communication, London: Routledge, 2013.

J. Arsenijevic, M. Andevski, \& M. Jockov, "Role of Communication in Classroom Management," The Anthropologist, vol. 28(1-2), pp. 69-78, 2017.

F. Bambaeeroo, \& N. Shokrpour, "The impact of the teachers' nonverbal communication on success in teaching," Journal of Advances in Medical Education \& Professionalism, 5(2), pp. 51-59, 2017.

M. H. Bornstein, Psychological insights for understanding COVID-19 and Families, Parents and Children, Routledge, 2020.

L. P. Calitz, O. La Fuglestad, \& S. Lillejord, Leadership in Education, Heinemann, 2002.

J. A. DeVito, Human communication. The basic course, Pearson, 2018.

D. R. Garrison, E-Learning in the $21^{\text {st }}$ century. Routledge, Taylor \& Francis, 2017.

S. Iordanidou, P. J. Stamatis, \& L. Valsamidou, "Communication in Education and Education in Media literacy a theoretical and research approach in the field of Preschool Education," in Theory and research methodology issues in Communication in Education, A. Kodakos and P. J. Stamatis, Eds., Athens: Diadrasi Publications, 2020, pp. 209-243.

V. W. Johnson, \& A. S. E. Johnson, No hugs. No bugs. : $1^{\text {st }}$ day of school after COVID-19. Independently published, 2020.

M. L. Knapp, \& J. A. Hall, Nonverbal communication in human interaction, Canada: WANTSWORTH CENGAGE Learning, 2010.

A. G. Kruger, \& O. J. Van Schalkwyk, Classroom Management, J. L. van Schaik Uitgewers Publishers, 1997.

D. Lemov, Teaching in the online classroom - Surviving and thriving in the new normal, Jossey-Bass, 2020.

G. T. Lynn, \& C. C. Johnson, Breaking the Trance: A practical guide for parenting the screen-dependent child, NV: Central Recovery Press, 2016.

J. C. McCroskey, V. P. Richmond, \& V. E. Bennett, "The relationships of student end-of-class motivation with teacher communication behaviors and instructional outcomes," Communication Education, vol. 55(4), pp. 403-414, 2006.

J. C. McCroskey, V. P. Richmond, \& L. L. McCroskey, An introduction to communication in the classroom. The role of communication in teaching and training, Pearson Education Inc, 2006.

V. Miller, \& A. Modi, $21^{\text {st }}$ century education through the lens of COVID-19, 2020.

J. E. Pyrgiotakis, Introduction to Pedagogy, Athens: Pedio Publications, 2011.

O. H. Sánchez, E-Learning in times of COVID-19. 2020.

C. J. Simonds, \& P. J. Cooper, Communication for the classroom teacher, Pearson Education Inc, 2011.

D. Solomon, \& J. Theiss, Interpersonal communication. Putting theory into practice, Routledge, Taylor \& Francis, 2013.

P. J. Stamatis, Communication in Education, Athens: Diadrasi Publications, 2013.

P. J. Stamatis, "Nonverbal immediacy in teaching: Examining views of Greek teachers of primary and secondary education, with self-assessment scale Nonverbal Immediacy Scale-Self Report (NIS-S)," in Nonverbal Communication in Education: Theory and practice, H. G. Klinzing, N. Polemikos, A. Kodakos, \& P. Stamatis (Eds.), Athens: Diadrasi Publications, pp. 321-363, 2014.

P. J Stamatis, Preschool and Primary Pedagogy. Communication dimensions of the educational process, Athens: Diadrasi Publications, 
2015.

P. J. Stamatis, "Communication Literacy and Preschool Education in $21^{\text {st }}$ century," in Theories and Communication Models in Education, A Kodakos and P. J. Stamatis, Eds., Athens: Diadrassi Publications, pp. 347$368,2017$.

P. J. Stamatis, \& E. N. Nikolaou (Eds.), Violent Communication and Bullying in Early Childhood Education, NY: Nova Science Publishers, Inc, 2018.

P. J. Stamatis, \& G. A. Goutziamanis, "Communication competence as fundamental aspect for effective school leader and administration achieving: A synoptic theoretical approach", European Journal of Education Studies, vol. 7(11), pp. 19-31, 2020.

P. J. Stamatis, \& A. M. Hatzinikolaou, "Practices of Greek school principals for improving school climate as communication strategy," European Journal of Human Resource Management Studies, vol. 4(2), pp. 93-107, 2020.

P. J. Stamatis, \& E. N. Nikolaou, Communication and Mental Health Promotion in Early Childhood Education, NY: Nova Science Publishers, Inc, 2020.

P. J. Stamatis, \& V. E. Kostoula, "Nonverbal immediacy in teaching process: A study in secondary education," European Journal of Education and Pedagogy, vol. 2(1), pp. 20-24, 2021.

S. Ratcliffe (Eds.), Oxford Essential Quotations. Oxford University Press, 2017.

R. Walsh, Education in the 21st century: Navigating education reform to get the best education for my child, NY: Garn Press, 2016.

J. Velez, \&, J. Cano, "Instructor Verbal and Nonverbal Immediacy and the Relationship with Student Self-efficacy and Task Value Motivation," Journal of Agricultural Education, vol. 53(2), pp. 87-98, 2012.

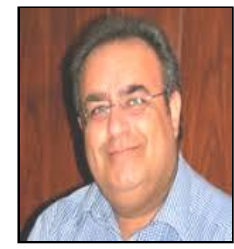

Panagiotis J. Stamatis is Associate Professor of Communication in Preschool and Early Primary School Education in the Department of Sciences of Preschool Education and Educational Design, University of the Aegean, Greece. At the same university he studied the Sciences of Preschool and Elementary School Education and he completed his $\mathrm{PhD}$ studies with honors in Pedagogical Communication putting emphasis on Nonverbal Communication in Preschool Education. Since 1989 to 2012 he worked in Primary School Education (PSE), reaping great teaching and administrative experience. He left PSE while he was an Elementary School Teachers' Counselor.

He has participated in many conferences as delegate and/or member of several scientific and organizing committees, in educational and research projects and teachers' training programs. He has published pedagogical books in Greece and USA, himself and/or in collaboration. Also, he has reviewed and published several articles in journals, conference proceedings and book chapters. He has given lectures in various institutions and universities. He is a member of the Greek Pedagogical Association and awarded for his writings and social contribution. 